\title{
Sistem Pendukung Keputusan Pemilihan Vendor Telekomunikasi Pada PT. Indosat Menggunakan Metode Analitycal Hierarchy Process (AHP)
}

\author{
Muhamad Sauqie ${ }^{1}$, Imam Budiawan'2, Ispandi $^{3}$ \\ 1,2,3 Universitas Nusamandiri \\ e-mail: ${ }^{1}$ Ogiewarning@gmail.com, ${ }^{2}$ imam121281@gmail.com, ${ }^{3}$ Ispandi.ipd@ nusamandiri.ac.id

\begin{tabular}{ccc}
\hline Diterima & Direvisi & Disetujui \\
$29-11-2021$ & $02-12-2021$ & $10-12-2021$ \\
\hline
\end{tabular}

\begin{abstract}
Abstrak - Perkembangan teknologi sangat berpengaruh terhadap seluruh aspek kehidupan manusia baik dalam bidang pendidikan,ekonomi, bisnis, maupun organisasi lainnya. Penggunaan sebuah metode dalam menunjang pengambilan keputusan pun sudah banyak diterapkan, dikarenakan dapat membantu manajemen dalam mengambil sebuah keputusan. Tujuan penelitian untuk tidak terjadi kesalahan dalam pengumpulan data, dan proses yang lebih baik lagi apabila memiliki banyak kriteria, sehingga memperoleh hasil yang diharapkan oleh penyedia jasa menggunakan hasil perhitungan Analytical Hierarchy Process (AHP), diperoleh prioritas kriteria dalam penilaian terhadap pemilihan vendor telekomunikasi. Permasalahannya adalah saat ini PT. Indosat belum dapat menentukan cara memilih vendor yang terbaik. Dan mungkin akan sulit menemukan metode mana yang akan memiliki nilai yang lebih relevan diantara metode yang sudah diterapkan sebelumnya dengan metode AHP. Oleh karena itu perlu dilakukan pengujian terhadap hasil dari metode tersebut dengan uji reliabilitas guna melihat kekuatan hubungan dari hasil yang didapatkan dengan hasil keputusan yang dibuat yang dapat menghasilkan hasil yang sangat akurat dalam memilih vendor terbaik dalam telekomunikasi.
\end{abstract}

\section{Kata Kunci: Sistem penunjang Keputusan, Analytical Hierarchy Process (AHP), Pemilihan Vendor.}

Abstract - The development of technology is very influential on all aspects of human life both in the fields of education, economy, business, and other organizations. The use of a method in supporting decision making has also been widely applied, because it can assist management in making a decision. The purpose of the research is to avoid errors in data collection, and to make the process even better if it has many criteria, so as to obtain the results expected by service providers using the results of the Analytical Hierarchy Process (AHP) calculation, obtaining priority in the assessment of the selection of telecommunication vendors. The problem is that currently PT. Indosat has not been able to determine how to choose the best vendor. And it may be difficult to find which method will have more relevant value among the previously implemented methods with the AHP method. Therefore, it is necessary to test the results of the method with a reliability test in order to see the strength of the relationship between the results obtained and the results of decisions made that can produce very accurate results in choosing the best vendor in telecommunications.

Keywords: Decision Support System, Analytical Hierarchy Process (AHP), Vendor Selection.

\section{PENDAHULUAN}

Dalam manajemen pengambil keputusan tentunya dituntut untuk menghasilkan sebuah keputusan secara cepat dan tepat guna menerapkan kebijakan yang akan dilakasanakan. Penggunaan sebuah metode dalam menunjang pengambilan keputusan pun sudah banyak diterapkan, dikarenakan dapat membantu manajemen dalam mengambil sebuah keputusan. Selain itu penggunaan sebuah metode penunjang keputusan juga dianggap lebih memiliki nilai objektif yang tinggi dibandingkan dengan sistem manual yang bisa saja keputusan yang diambil akan sangat subjektif, membutuhkan waktu yang lama dan bisa saja hal yang paling tidak diinginkan terjadi yaitu adanya kesalahan dalam pengambilan keputusan.

Perusahaan yang dapat memadukan dengan baik antara strategi, teknologi, dan sumber daya yang ada, akan dapat bertahan dengan baik dalam persaingan dengan perusahaan yang bergerak di bidang industri yang sama. Hal tersebut dapat terwujud dengan penentuan supplier atau pemasok yang tepat.

Salah satu faktor yang mempengaruhi kinerja perusahaan adalah keberadaan supplier, sehingga pemilihan supplier yang tepat bagi perusahaan merupakan salah satu pengambilan keputusan yang sangat penting yang perlu dilakukan oleh setiap perusahaan yang melibatkan supplier dalam kegiatan bisnisnya (Hasiani et al., 2021). 
Supplier merupakan salah satu bagian terpenting dalam suatu perusahaan penyedia jasa konstruksi.(Handayani \& Darmianti, 2017). Menurut(Sitio, 2017) , supplier atau pemasok merupakan mitra bisnis yang memegang peranan sangat penting dalam menjamin ketersediaan barang pasokan yang dibutuhkan oleh perusahaan. kinerja supplier atau pemasok akan mempengaruhi performansi atau kinerja perusahaan.

Oleh karena itu, perusahaan perlu menilai vendor atau supplier secara cermat dan tepat. Penilaian yang dilakukan kepada supplier selama ini bersifat subyektif, sehingga tidak dapat menjamin tingkat konsistensi penilaian.(Haryanto \& Sadeyah, 2018). Penentuan pemasok merupakan kegiatan strategis, terutama apabila pemasok tersebut akan memasok item yang penting dan akan digunakan dalam jangka panjang.

Sistem pendukung keputusan merupakan alternatif solusi atau alternatif tindakan dari sejumlah alternatif solusi dan tindakan guna menyelesaikan suatu masalah, sehingga masalah tersebut dapat diselesaikan secara efektif dan efisien.(Irfan \& Siregar, 2017)

Analytical Hierarchy Process (AHP) adalah teknik terstruktur yang digunakan untuk menganalisis masalah yang kompleks, di mana sejumlah besar tujuan atau kriteria saling terkait. Bobot kriteria ini ditentukan setelah mereka diberi peringkat menurut kepentingan relatifnya. Jadi, setelah semua kriteria diurutkan secara hierarkis, matriks perbandingan berpasangan untuk setiap kriteria dibuat untuk memungkinkan perbandingan signifikan. Signifikansi relatif antara kriteria dievaluasi dari 1 hingga 9 yang menunjukkan kriteria yang kurang penting hingga kriteria yang jauh lebih penting (Kazakis et al., 2015).

Pengambilan keputusan dalam penentuan hasil menggunakan metode AHP, dikarenakan memiliki performa yang baik untuk menganalisis kebijakan yang melibatkan kriteria kualitatif dan kuantitatif. Selain itu, sistem pendukung keputusan dengan mencampur beberapa metode perhitungan diharapkan menghasilkan hasil yang baik (Althuwaynee et al., 2014). Penerapan Analytical Hierarchy Process (AHP) yang bertujuan untuk menghitung prioritas setiap alternatif terhadap serangkaian kriteria dengan hanya $\mathrm{n}-1$ perbandingan alternatif untuk setiap kriteria, diikuti dengan penerapan rumus sederhana. Hal ini meningkatkan daya tarik metode AHP untuk aplikasi bisnis di mana pengambil keputusan bertumpu pada batasan waktu (Leal, 2020).

Dalam sistem pendukung keputusan terdapat metode Analytical Hierarchy Process (AHP) yang dapat digunakan dalam pemecahan masalah yang bersifat obyektif dan dapat juga digunakan untuk memecahkan masalah dalam penelitian ini.

\section{Sistem Pendukung Keputusan}

Sistem Pendukung Keputusan (SPK) merupakan suatu sistem informasi yang menghasilkan bermacam alternatif keputusan yang bertujuan membantu manajemen dalam menangani permasalahan secara terorganisir maupun tidak berdasarkan data dan model tertentu dan berdasarkan pendekatan kuantitatif dalam proses penentuan keputusan. (Nurajizah et al., 2020)

\section{Analitical Hieracy Proces (AHP)}

Dalam industri manufaktur maupun jasa, pengambil keputusan sering kali dihadapkan suatu permasalah yang kompleks. Salah satu permasalahan yang tersebut adalah masalah menentukan pilihan dari beberapa kandidat atau sekadar mengurutkan prioritas dari beberapa kandidat.(Prihartono \& Magdalena, 2016)

Tujuan penelitian yang penulis lakukan yaitu untuk mendapatkan hasil yang akurat dari pemilihan vendor telekomunikasi ; untuk memudahkan proses pemilihan vendor telekomunikasi sehingga tidak terlalu membutuhkan proses yang panjang; dan menciptakan suasana baik dan harmonis. Sehingga penulis mengusulkan metode AHP sebagai acuan pendukung keputusan yang dapat menghasilkan keputusan yang lebih baik.

Beberapa metode telah diadopsi untuk menghitung bobot untuk menggambarkan zona potensi airtanah seperti model indeks, rasio frekuensi (FR), faktor kepastian (CF), bobot bukti (WOE), logika fuzzy, multi--faktor yang mempengaruhi (MIF) dll. Di antara teknik-teknik ini, proses hierarki analitis (AHP) menjadi teknik pelopor dalam pemodelan prediksi yang dapat memberikan hasil yang cepat, tepat dan hemat biaya(Murmu et al., 2019).

\section{METODE PENELITIAN}

1. Rancangan Penelitian

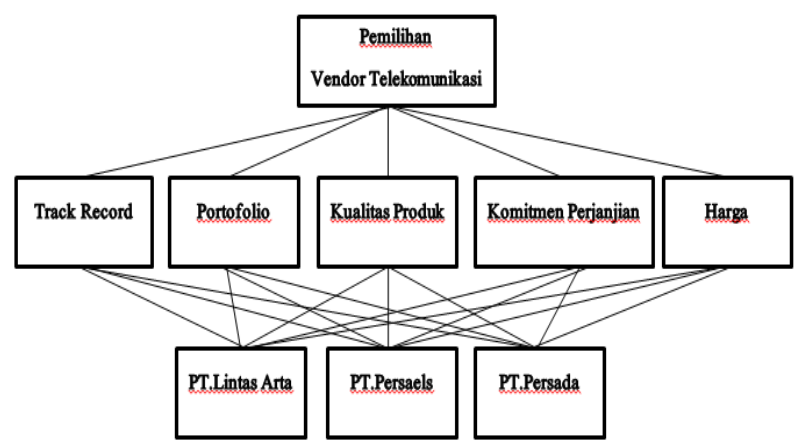

Sumber: Sauqi (2019)

Gambar 1. Metode Penelitian 
Tabel1. Skala Penilaian Perbandingan Pasangan

\begin{tabular}{|c|l|}
\hline $\begin{array}{c}\text { Intensitas } \\
\text { Kepentingan }\end{array}$ & \multicolumn{1}{|c|}{ Keterangan } \\
\hline 1 & Kedua elemen yang sama pentingnya \\
\hline 3 & $\begin{array}{l}\text { Elemen yang satu sedikit lebih penting } \\
\text { daripada elemen yang lainnya }\end{array}$ \\
\hline 5 & $\begin{array}{l}\text { Elemen yang satu lebih penting daripada } \\
\text { elemen yang lainnya }\end{array}$ \\
\hline 7 & $\begin{array}{l}\text { Satu elemen jelas lebih mutlak penting } \\
\text { daripada elemen lainnya }\end{array}$ \\
\hline 9 & $\begin{array}{l}\text { Satu elemen mutlak penting daripada } \\
\text { elemen lainnya }\end{array}$ \\
\hline $2,4,6,8$ & $\begin{array}{l}\text { Nilai-nilai antara dua nilai pertimbangan } \\
\text { yang berdekatan }\end{array}$ \\
\hline Kebalikan & $\begin{array}{l}\text { Jika aktivitas I mendapat satu angka } \\
\text { dibandingkan dengan aktivitas } \mathrm{j} \text {, maka } \mathrm{j} \\
\text { memiliki nilai kebalikannya dibandingkan } \\
\text { dengan i }\end{array}$ \\
\hline
\end{tabular}

Sumber : (Pratiwi, 2020)

Penulis merancang penelitian ini bersumber dari data primer di PT.Indosat dengan observasi langsung dengan pihak terkait

\section{Sumber Data}

Berdasarkan beberapa tinjauan studi, penulis melakukan penelitian kasus pemilihan vendor telekomunikasi di PT. Indosat melalui observasi langsung dengan kepala divison Head .Penelitian ini menggunakan metode Analitical Hierarcy Proces (AHP). Variabel dalam pemilihan vendor telekomunikasi berdasarkan track record, portofolio, kualitas produk, komitmen perjanjian, dan harga. Hasil pengolahan data dengan menggunakan Analitical Hierarcy Proces (AHP).

\section{Populasi dan Sampel Penelitian}

Sampel Penelitian yang penulis gunakan di ambil dari karyawan PT. Indosat

\section{Jurnal penelitian}

Sebagai bahan acuan penulis banyak mengambil referensi dari beberapa jurnal dengan masalah yang sama yang berhubungan dengan PT. Indosat.

\section{Tehnik Pengumpulan Data}

Teknik pengumpulan data yang penulis lakukan yaitu obervasi, wawancara, dan kuesioner. Berikut penjelasannya :

Penulis melakukan observasi dengan pihak PT. Indosat Dalam penelitian ini penulis melakukan observasi secara lengkap di PT. Indosat, dimana dalam pengumpulan data penulis sudah terlibat sepenuhnya.

Pada teknik wawancara ini, penulis melakukan tanya jawab langsung kepada Bapak Abdul Bahri sebagai narasumber.

Pada tahapan koesioner, penulis menyebarkan sample sebanyak 6 responden pertanyaan kepada karyawan untuk mengetahui hasil vendor telekomunikasi.

\section{Metode Penelitian dan Analisis}

Metode yang di pakai dalam penelitian ini adalah merubah nilai-nilai kualitatif menjadi kuantitatif Sehingga keputusan yang di ambil bisa lebih objektif.

\section{Prosedur AHP}

Pada dasarnya, prosedur atau langkah-langkah dalam metode AHP meliputi:

a. Mendefinisikan masalah dan menentukan solusi yang diinginkan, lalu menyusun hierarki dari permasalahan yang dihadapi. Penyusunan hierarki adalah dengan menetapkan tujuan yang merupakan sasaran sistem secara keseluruhan pada level teratas.

b. Menentukan prioritas elemen

1) Langkah pertama dalam menentukan prioritas elemen adalah membuat perbandingan pasangan, yaitu membandingkan elemen secara berpasangan sesuai kriteria yang diberikan.

2) Matriks perbandingan berpasangan diisi menggunakan bilangan untuk merepresentasikan kepentingan relatif dari suatu elemen terhadap elemen yang lainnya.

c. Sistesis

Pertimbangan-pertimbangan terhadap perbandingan berpasangan disintesis untuk memperoleh keseluruhan prioritas. Hal-hal yang dilakukan dalam langkah ini adalah:

1) Menjumlahkan nilai-nilai dari setiap kolom pada matriks

2) Membagi setiap nilai dari kolom dengan total kolom yang bersangkutan untuk memperoleh normalisasi matriks

3) Menjunlahkan nilai-nilai dari setiap baris dan membaginya dengan jumlah elemen untuk mendapatkan nilai rata-rata

d. Mengukur Konsistensi

Dalam pembuatan keputusan, penting untuk mengetahui seberapa baik konsistensi yang ada karena kita tidak menginginkan keputusan berdasarkan pertimbangan dengan konsistensi yang rendah. Hal-hal yang dilakukan dalam langkah ini adalah:

1) Kalikan setiap nilai pada kolom pertama dengan prioritas relatif elemen pertama, 
nilai pada kolom kedua dengan prioritas relatif elemen kedua, dan seterusnya

2) Jumlahkan setiap baris

3) Hasil dari penjumlahan baris dibagi dengan elemen prioritas relatif yang bersangkutan

4) Jumlahkan hasil bagi diatas dengan banyaknya elemen yang ada, hasilnya disebut $\lambda$ maks

e. Hitung Consistency Index (CI) dengan rumus: $\mathrm{CI}=(\lambda$ maks $-\mathrm{n}) / \mathrm{n}$

Dimana $\mathrm{n}=$ banyaknya elemen

f. Hitung Rasio Konsistensi / Consistency Ratio (CR) dengan rumus:

$\mathrm{CR}=\mathrm{CI} / \mathrm{RC}$

Dimana CR = Consistency Ratio

$\mathrm{CI}=$ Consistency Index

$\mathrm{IR}=$ Indeks Random Consistency

g. Memeriksa konsistensi hierarki. Jika nilainya lebih dari $10 \%$, maka penilaian data judgment harus diperbaiki. Namun jika rasio konsistensi (CI/IR) kurang atau sama dengan 0,1, maka hasil perhitungan bisa dinyatakan benar.

\section{HASIL DAN PEMBAHASAN}

Dalam pengolahan hasil penelitian, penulis menetapkan langkah-langkah penyelesaian yang sesuai dengan proses pemecahan masalah dalam AHP dimana ada empat tahap yaitu mendefinisikan masalah, menentukan prioritas elemen, sintesis dan mengukur konsistensi

\section{Menentukan Prioritas Elemen}

Pada tahapan menentukan prioritas elemen, langkah yang dilakukan pertama adalah membuat matriks perbandingan pasangan, yaitu membandingkan elemen secara berpasangan sesuai kriteria yang telah diberikan. Matriks perbandingan berpasangan diisi dengan menggunakan angka untuk menggambarkan tingkat kepentingan dari suatu elemen terhadap elemen yang lain.

2. Pengolahan Data Manual

a. Kriteria utama

Tabel 2. Matriks Kriteria Utama

\begin{tabular}{|l|l|l|l|l|l|}
\hline \multicolumn{6}{|l|}{ Penjumlahan Kolom Matrik Berdasarkan Kriteria Utama } \\
\hline Kriteria & $\begin{array}{l}\text { Track } \\
\text { Record }\end{array}$ & $\begin{array}{l}\text { Porto } \\
\text { folio }\end{array}$ & $\begin{array}{l}\text { Kualitas } \\
\text { Produk }\end{array}$ & $\begin{array}{l}\text { Komitmen } \\
\text { Perjanjian }\end{array}$ & Harga \\
\hline $\begin{array}{l}\text { Track } \\
\text { Record }\end{array}$ & 1,00 & 1,88 & 0,49 & 3,80 & 1,57 \\
\hline Portofolio & 0,53 & 1,00 & 1,83 & 1,99 & 1,58 \\
\hline $\begin{array}{l}\text { Kualitas } \\
\text { Produk }\end{array}$ & 2,04 & 0,55 & 1,00 & 1,74 & 6,63 \\
\hline $\begin{array}{l}\text { Komitment } \\
\text { Perjanjian }\end{array}$ & 0,26 & 0,50 & 0,57 & 1,00 & 1,08 \\
\hline Harga & 0,64 & 0,31 & 0,15 & 0,51 & 1,00 \\
\hline TOTAL & $\mathbf{4 , 4 7}$ & $\mathbf{4 , 2 3}$ & $\mathbf{4 , 0 5}$ & $\mathbf{9 , 0 5}$ & $\mathbf{1 1 , 8 6}$ \\
\hline
\end{tabular}

Sumber : Data Penelitian 2019 b. Kriteria utama

Tabel 3. Normalisasi Matriks Kriteria Utama

\begin{tabular}{|l|c|c|c|c|c|c|}
\hline \multicolumn{7}{|c|}{ Normalisasi Matrik Berdasarkan Kriteria Utama } \\
\hline Kriteria & $\begin{array}{c}\text { Track } \\
\text { Record }\end{array}$ & $\begin{array}{c}\text { Porto } \\
\text { folio }\end{array}$ & $\begin{array}{c}\text { Kualitas } \\
\text { Produk }\end{array}$ & $\begin{array}{c}\text { Komitment } \\
\text { Perjanjian }\end{array}$ & Harga & $\begin{array}{c}\text { Rata- } \\
\text { rata }\end{array}$ \\
\hline $\begin{array}{l}\text { Track } \\
\text { Record }\end{array}$ & 0,22 & 0,44 & 0,12 & 0,42 & 0,13 & $\mathbf{0 , 2 7}$ \\
\hline Portofolio & 0,12 & 0,24 & 0,45 & 0,22 & 0,13 & $\mathbf{0 , 2 3}$ \\
\hline $\begin{array}{l}\text { Kualitas } \\
\text { Produk }\end{array}$ & 0,46 & 0,13 & 0,25 & 0,19 & 0,56 & $\mathbf{0 , 3 2}$ \\
\hline $\begin{array}{l}\text { Komitment } \\
\text { Perjanjian }\end{array}$ & 0,06 & 0,12 & 0,14 & 0,11 & 0,09 & $\mathbf{0 , 1 0}$ \\
\hline Harga & 0,14 & 0,07 & 0,04 & 0,06 & 0,08 & $\mathbf{0 , 0 8}$ \\
\hline \multicolumn{7}{|c|}{} \\
\hline
\end{tabular}

Sumber : Data Penelitian 2019

$\lambda$ Maks $=5,3569$

$\mathrm{Cl}=\frac{(\lambda \text { maks }-\mathrm{n})}{(\mathrm{n}-1)}=\frac{(5,3569-5)}{(5-1)}=0.0892$

$\mathrm{CR}=\frac{\mathrm{CI}}{\mathrm{RI}}=\frac{0,0892}{1,12}=0,0797$

c. Kriteria Track Record

Tabel 4. Matriks Kriteria Track Record

\begin{tabular}{|l|c|c|c|}
\hline \multicolumn{4}{|c|}{ Penjumlahan Kolom Matrik Berdasarkan } \\
Track Record \\
\hline Kriteria & $\begin{array}{c}\text { PT . Lintas } \\
\text { Arta }\end{array}$ & $\begin{array}{c}\text { PT. } \\
\text { Persaels }\end{array}$ & PT. Persada \\
\hline $\begin{array}{l}\text { PT. Lintas } \\
\text { Arta }\end{array}$ & 1,00 & 1,37 & 0,74 \\
\hline PT. Persaels & 0,73 & 1,00 & 0,74 \\
\hline PT. Persada & 1,35 & 1,34 & 1,00 \\
\hline TOTAL & $\mathbf{3 , 0 7}$ & $\mathbf{3 , 7 1}$ & $\mathbf{2 , 4 8}$ \\
\hline
\end{tabular}

Sumber : Data Penelitian 2019)

d. Kriteria Track Record

Tabel 5.Normalisasi Matriks Kriteria Track Record

\begin{tabular}{|c|c|c|c|c|}
\hline \multicolumn{5}{|c|}{$\begin{array}{c}\text { Normalisasi Kolom Matrik Berdasarkan Track } \\
\text { record }\end{array}$} \\
\hline Kriteria & $\begin{array}{c}\text { PT . } \\
\text { Lintas } \\
\text { Arta }\end{array}$ & $\begin{array}{c}\text { PT. } \\
\text { Persaels }\end{array}$ & $\begin{array}{c}\text { PT. } \\
\text { Persada }\end{array}$ & $\begin{array}{c}\text { Rata- } \\
\text { rata }\end{array}$ \\
\hline $\begin{array}{l}\text { PT. Lintas } \\
\text { Arta }\end{array}$ & 0,33 & 0,37 & 0,30 & 0,33 \\
\hline $\begin{array}{l}\text { PT. } \\
\text { Persaels }\end{array}$ & 0,24 & 0,27 & 0,30 & 0,27 \\
\hline $\begin{array}{l}\text { PT. } \\
\text { Persada }\end{array}$ & 0,44 & 0,36 & 0,40 & 0,40 \\
\hline \multicolumn{4}{|c|}{ Eigen Vector } & 1,00 \\
\hline
\end{tabular}

Sumber : Data Penelitian (2019)

$\lambda$ Maks $=3,0082$

$\mathrm{Cl}=\frac{(\lambda \text { maks }-\mathrm{n})}{(\mathrm{n}-1)}=\frac{(3,0082-3)}{(3-1)}=0,0041$

$C R=\frac{C I}{R I}=\frac{0,0041}{0,58}=0,0070$ 
e. Kriteria Portofolio

Tabel 6. Matriks Kriteria Portofolio

\begin{tabular}{|c|c|c|c|}
\hline \multicolumn{1}{|c|}{ Penjumlahan Kolom Matrik Berdasarkan Portofolio } \\
\hline Kriteria & $\begin{array}{c}\text { PT . Lintas } \\
\text { Arta }\end{array}$ & PT. Persaels & PT. Persada \\
\hline $\begin{array}{l}\text { PT. Lintas } \\
\text { Arta }\end{array}$ & 1,00 & 1,32 & 0,74 \\
\hline PT. Persaels & 0,75 & 1,00 & 0,74 \\
\hline PT. Persada & 1,35 & 1,34 & 1,00 \\
\hline TOTAL & $\mathbf{3 , 1 0}$ & $\mathbf{3 , 6 6}$ & $\mathbf{2 , 4 8}$ \\
\hline
\end{tabular}

Sumber : Data Penelitian (2019)

f. Kriteria Portofolio

Tabel 7. Normalisasi Matriks Kriteria Portofolio

\begin{tabular}{|c|c|c|c|c|}
\hline \multicolumn{5}{|c|}{ Normalisasi Kolom Matrik Berdasarkan Portofolio } \\
\hline Kriteria & $\begin{array}{l}\text { PT . } \\
\text { Lintas } \\
\text { Arta }\end{array}$ & $\begin{array}{c}\text { PT. } \\
\text { Persaels }\end{array}$ & $\begin{array}{c}\text { PT. } \\
\text { Persada }\end{array}$ & $\begin{array}{c}\text { Rata- } \\
\text { rata }\end{array}$ \\
\hline $\begin{array}{l}\text { PT. } \\
\text { Lintas } \\
\text { Arta }\end{array}$ & 0,32 & 0,36 & 0,30 & 0,33 \\
\hline $\begin{array}{l}\text { PT. } \\
\text { Persaels }\end{array}$ & 0,24 & 0,27 & 0,30 & 0,27 \\
\hline $\begin{array}{l}\text { PT. } \\
\text { Persada }\end{array}$ & 0,43 & 0,37 & 0,40 & 0,40 \\
\hline \multicolumn{4}{|c|}{ Eigen Vector } & 1,00 \\
\hline
\end{tabular}

Sumber : Data Penelitian (2019)

$\lambda$ Maks $=3,01636$

$\mathrm{CI}=\frac{(\lambda \text { maks }-\mathrm{n})}{(\mathrm{n}-1)}=\frac{(3,01636-3)}{(3-1)}=0,00818$

$\mathrm{CR}=\frac{\mathrm{CI}}{\mathrm{RI}}=\frac{0,00818}{0,58}=0,01411$

g. Kriteria Kualitas Produk

Tabel 8.Matriks Kriteria Kualitas Produk

\begin{tabular}{|l|c|c|c|}
\hline \multicolumn{4}{|c|}{ Penjumlahan Kolom Matrik Berdasarkan Kualitas } \\
Produk \\
\hline Kriteria & $\begin{array}{c}\text { PT . } \\
\text { Lintas Arta }\end{array}$ & $\begin{array}{c}\text { PT. } \\
\text { Persaels }\end{array}$ & PT. Persada \\
\hline $\begin{array}{l}\text { PT. } \\
\text { Lintas } \\
\text { Arta }\end{array}$ & 1,00 & 1,29 & 0,74 \\
\hline $\begin{array}{l}\text { PT. } \\
\text { Persaels }\end{array}$ & 0,77 & 1,00 & 0,74 \\
\hline $\begin{array}{l}\text { PT. } \\
\text { Persada }\end{array}$ & 1,35 & 1,34 & 1,00 \\
\hline TOTAL & $\mathbf{3 , 1 2}$ & $\mathbf{3 , 6 4}$ & $\mathbf{2 , 4 8}$ \\
\hline
\end{tabular}

Sumber : Data Penelitian (2019) h. Kriteria Kualitas Produk

Tabel 9. Normalisasi Matriks Kriteria Kualitas Produk

\begin{tabular}{|l|c|c|c|c|}
\hline \multicolumn{5}{|c|}{ Normalisasi Kolom Matrik Berdasarkan Kualitas } \\
Kroduk \\
\hline Kriteria & $\begin{array}{c}\text { PT . } \\
\text { Lintas } \\
\text { Arta }\end{array}$ & $\begin{array}{c}\text { PT. } \\
\text { Persaels }\end{array}$ & $\begin{array}{c}\text { PT. } \\
\text { Persada }\end{array}$ & $\begin{array}{c}\text { Rata- } \\
\text { rata }\end{array}$ \\
\hline $\begin{array}{l}\text { PT. } \\
\text { LintasArta }\end{array}$ & 0,32 & 0,36 & 0,30 & 0,33 \\
\hline $\begin{array}{l}\text { PT. } \\
\text { Persaels }\end{array}$ & 0,25 & 0,27 & 0,30 & 0,27 \\
\hline $\begin{array}{l}\text { PT. } \\
\text { Persada }\end{array}$ & 0,43 & 0,37 & 0,40 & 0,40 \\
\hline & \multicolumn{5}{|c|}{ Eigen Vector } & 1,00 \\
\hline
\end{tabular}

Sumber : Sauqie (2019)

$\lambda$ Maks $=3,0026$

$\mathrm{Cl}=\frac{(\lambda \text { maks }-\mathrm{n})}{(\mathrm{n}-1)}=\frac{(3,002-3)}{(3-1)}=0,0013$

$\mathrm{CR}=\frac{\mathrm{CI}}{\mathrm{RI}}=\frac{0,0013}{0,58}=0,0023$

i. Kriteria Komitmen Perjanjian

Tabel 10. Matriks Kriteria Komitmen Perjanjian

\begin{tabular}{|l|c|c|c|}
\hline \multicolumn{4}{|c|}{ Penjumlahan Kolom Matrik Berdasarkan Komitmen } \\
Perjanjian
\end{tabular}

Sumber : Data Penelitian (2019)

j. Kriteria Komitmen Perjanjian

Tabel 11. Normalisasi Matriks Kriteria Komitmen Perjanjian

\begin{tabular}{|c|c|c|c|c|}
\hline \multicolumn{5}{|c|}{$\begin{array}{c}\text { Normalisasi Kolom Matrik Berdasarkan Komitment } \\
\text { Perjanjian }\end{array}$} \\
\hline Kriteria & $\begin{array}{c}\text { PT . } \\
\text { LintasArta }\end{array}$ & $\begin{array}{c}\text { PT. } \\
\text { Persaels }\end{array}$ & $\begin{array}{l}\text { PT. } \\
\text { Persada }\end{array}$ & $\begin{array}{l}\text { Rata- } \\
\text { rata }\end{array}$ \\
\hline $\begin{array}{l}\text { PT. } \\
\text { LintasArta }\end{array}$ & 0,32 & 0,34 & 0,30 & 0,32 \\
\hline $\begin{array}{l}\text { PT. } \\
\text { Persaels }\end{array}$ & 0,26 & 0,28 & 0,30 & 0,28 \\
\hline $\begin{array}{l}\text { PT. } \\
\text { Persada }\end{array}$ & 0,42 & 0,38 & 0,40 & 0,40 \\
\hline \multicolumn{4}{|c|}{ Eigen Vector } & 1,00 \\
\hline
\end{tabular}

Sumber : Data Penelitian (2019) 
$\lambda$ Maks $=3,0024$

$\mathrm{CI}=\frac{(\lambda \text { maks }-\mathrm{n})}{(\mathrm{n}-1)}=\frac{(3,0024-3)}{(3-1)}=0,0012$

$\mathrm{CR}=\frac{\mathrm{CI}}{\mathrm{RI}}=\frac{0,0012}{0,58}=0,0021$

k. Kriteria Harga

Tabel 12. Matriks Kriteria Harga

\begin{tabular}{|l|c|c|c|}
\hline \multicolumn{3}{|c|}{ Penjumlahan Kolom Matrik Berdasarkan Harga } \\
\hline Kriteria & $\begin{array}{c}\text { PT . Lintas } \\
\text { Arta }\end{array}$ & PT. Persaels & PT. Persada \\
\hline $\begin{array}{l}\text { PT. Lintas } \\
\text { Arta }\end{array}$ & 1,00 & 1,21 & 0,74 \\
\hline $\begin{array}{l}\text { PT. } \\
\text { Persaels }\end{array}$ & 0,83 & 1,00 & 0,79 \\
\hline $\begin{array}{l}\text { PT. } \\
\text { Persada }\end{array}$ & 1,35 & 1,26 & 1,00 \\
\hline TOTAL & $\mathbf{3 , 1 7}$ & $\mathbf{3 , 4 7}$ & $\mathbf{2 , 5 3}$ \\
\hline
\end{tabular}

Sumber : Sauqie (2019)

i. Kriteria Harga

Tabel 13. Normalisasi Matriks Kriteria Harga

\begin{tabular}{|c|c|c|c|c|}
\hline \multicolumn{5}{|c|}{ Normalisasi Kolom Matrik Berdasarkan Harga } \\
\hline Kriteria & $\begin{array}{l}\text { PT . } \\
\text { Lintas } \\
\text { Arta }\end{array}$ & $\begin{array}{c}\text { PT. } \\
\text { Persaels }\end{array}$ & $\begin{array}{c}\text { PT. } \\
\text { Persada }\end{array}$ & $\begin{array}{c}\text { Rata- } \\
\text { rata }\end{array}$ \\
\hline $\begin{array}{l}\text { PT. } \\
\text { LintasArta }\end{array}$ & 0,32 & 0,35 & 0,29 & 0,32 \\
\hline $\begin{array}{l}\text { PT. } \\
\text { Persaels }\end{array}$ & 0,26 & 0,29 & 0,31 & 0,29 \\
\hline $\begin{array}{l}\text { PT. } \\
\text { Persada }\end{array}$ & 0,42 & 0,36 & 0,39 & 0,39 \\
\hline \multicolumn{4}{|c|}{ Eigen Vector } & 1,00 \\
\hline
\end{tabular}

Sumber : Sauqie (2019)

$\lambda$ Maks $=3,0071$

$\mathrm{Cl}=\frac{(\lambda \text { maks }-\mathrm{n})}{(\mathrm{n}-1)}=\frac{(3,0071-3)}{(3-1)}=0,0035$

$C R=\frac{C I}{R I}=\frac{0,0035}{0,58}=0,0061$

Hasil Akhir Pengolahan Data Manual

$\left[\begin{array}{ccccc}0,33 & 0,33 & 0,3 & 0,33 & 0,32 \\ 0,27 & 0,27 & 0,3 & 0,27 & 0,29 \\ 0,4 & 0,4 & 0,4 & 0,4 & 0,39\end{array}\right] \times\left[\begin{array}{c}0,27 \\ 0,23 \\ 0,32 \\ 0,1 \\ 0,08\end{array}\right]=$
$\left[\begin{array}{l}0,326 \\ 0,275 \\ 0,399\end{array}\right]$

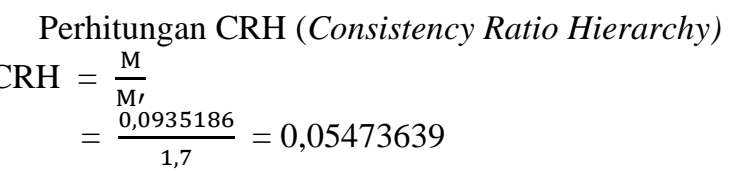

Karena nilai $\mathrm{CRH}<0,1 \quad(10 \%)$, maka hirarki secara keseluruhan bersifat "konsisten", sehingga kesimpulan yang diperoleh "dapat diterima".
Artinya keputusan yang ditetapkan dapat diandalkan.

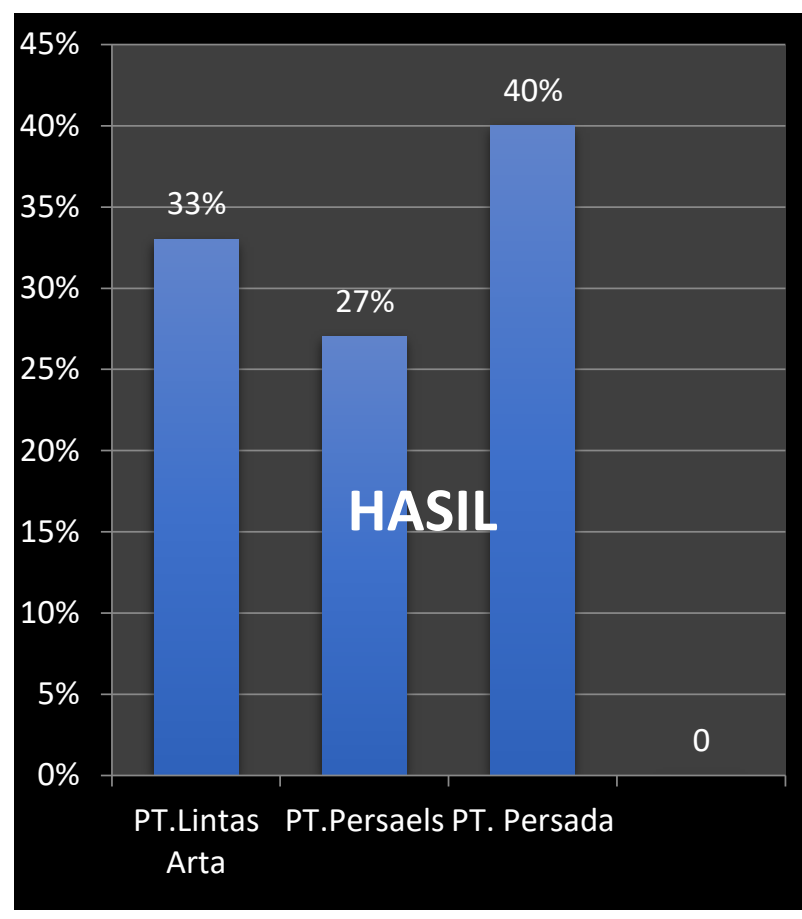

Gambar 2. Grafik Hasil Akhir Perhitungan Manual

Berdasarkan grafik output synthesize menunjukkan bahwa dalam pemilihan vendor telekomunikasi PT. Persada menempati posisi pertama dengan nilai 0,40 , kemudian PT. Lintas Arta dengan nilai 0,33 , dan PT. Persaels dengan nilai 0,27 .

\section{KESIMPULAN}

Berdasarkan hasil analisa dan pengolahan data yang dilakukan oleh penulis, maka dapat diambil beberapa kesimpulan, yaitu:

Dalam penelitian ini terdapat lima kriteria utama yang digunakan dalam pemilihan vendor telekomunikasi ini, yaitu track record, portofolio, kualitas produk, komitmen perjanjian, dan harga, dimana dapat disimpulkan bahwa tingkat keakuratan dalam menentukan vendor telekomunikasi dengan menggunakan metode AHP ini dapat dinilai dari Consistency Ratio Hierarchy / $\mathrm{CRH}<10 \%$, maka hasil perhitungan dapat dinyatakan benar, dalam skripsi ini perhitungan Consistency Ratio Hierarchy/CRH adalah 0,054 atau 5,4\% itu artinya nilai dapat diterima dan hasil perhitungan dinyatakan benar.

\section{REFERENSI}

Althuwaynee, O. F., Pradhan, B., Park, H. J., \& Lee, J. H. (2014). A novel ensemble bivariate statistical evidential belief function with 
knowledge-based analytical hierarchy process and multivariate statistical logistic regression for landslide susceptibility mapping. Catena, 114 , 21-36. https://doi.org/10.1016/j.catena.2013.10.011

Handayani, rani irma, \& Darmianti, Y. (2017). Sistem Pendukung Keputusan Pemilihan Supplier Dengan Metode Analytical Hierarchy Process Pada Pt. Cipta Nuansa Prima Tangerang. Jurnal Techno Nusa Mandiri, 14(2), 103-110.

Haryanto, K. W., \& Sadeyah, S. A. (2018). Sistem Pendukung Keputusan Pemilihan Supplier Bahan Baku Pada Cv . Sinar Agung Perkasa Menggunakan. Jurnal Spirit, 10(2), 1-8.

Hasiani, F. M. U., Haryanti, T., Rinawati, R., \& Kurniawati, L. (2021). Sistem Pendukung Keputusan Pemilihan Supplier Produk Ritel dengan Metode Analytical Hierarchy Process. Sistemasi, $10(1), \quad 139$. https://doi.org/10.32520/stmsi.v10i1.1125

Irfan, M., \& Siregar, D. (2017). BERLANGGANAN MENERAPKAN METODE ANALYTICAL HIERARCHY PROCESS ( AHP ). 1(2), 42-48.

Kazakis, N., Kougias, I., \& Patsialis, T. (2015). Assessment of flood hazard areas at a regional scale using an index-based approach and Analytical Hierarchy Process: Application in Rhodope-Evros region, Greece. Science of the Total Environment, 538, 555-563. https://doi.org/10.1016/j.scitotenv.2015.08.055
Leal, J. E. (2020). AHP-express: A simplified version of the analytical hierarchy process method. MethodsX, 7. https://doi.org/10.1016/j.mex.2019.11.021

Murmu, P., Kumar, M., Lal, D., Sonker, I., \& Singh, S. K. (2019). Delineation of groundwater potential zones using geospatial techniques and analytical hierarchy process in Dumka district, Jharkhand, India. Groundwater for Sustainable Development, 9(October 2018), 100239. https://doi.org/10.1016/j.gsd.2019.100239

Nurajizah, S., Ambarwati, N. A., \& Muryani, S. (2020). Sistem Pendukung Keputusan Pemilihan Internet Service Provider Terbaik Dengan Metode Analytical Hierarchy Process. JURTEKSI (Jurnal Teknologi Dan Sistem Informasi), 6(3), 231-238. https://doi.org/10.33330/jurteksi.v6i3.632

Pratiwi, H. (2020). TUJUAN dan KARAKTERISTIK SPK. May.

Prihartono, Y., \& Magdalena, H. (2016). Penerapan Metode Analytical Hierarchy Process ( AHP ) Sebagai Pendukung Keputusan dalam Menentukan Internet Service Provider Terbaik di Pangkalpinang. Sisfokom, 05, 21-32.

Sitio, A. S. (2017). Sistem Pendukung Keputusan Penentuan Supplier Pembelian Barang Menggunakan Metode Analitical Hierarchy Process Pada PT. Perintis Sarana Pancing Indonesia. Journal of Informatic Pelita Nusantara, 2(1), 40-47. 